\title{
Perencanaan Hotel Resort Wisata Danau Bandar Khayangan Lembah Sari Pekanbaru
}

\author{
Surya $^{1}$, Titin Sundari ${ }^{2}$, Imbardi $^{3}$ \\ 1,2,3 Program Studi Arsitektur, Fakultas Teknik, Universitas Lancang Kuning Pekanbaru. \\ Jl. Yos Sudarso km. 8 Rumbai, Pekanbaru, Telp. (0761) 52324 \\ Email: Suryabintan91@gmail.com, titin@unilak.ac.id,imbardi@unilak.ac.id
}

\begin{abstract}
ABSTRAK
Hotel Resort adalah sebuah wadah arsitektural dalam bentuk hunian penginapan yang dibangun untuk memfasilitasi para wisatawan mancan negara atau wisatawan lokal Pekanbaru yang datang berkunjung ke sebuah daerah atau objek wisata untuk menikmati fasilitas-fasilitas atau tempat-tempat wisata yang ada.Keberadaan wadah ini sudah cukup banyak tetapi masih sedikit yang menyediakan hunian Hotel Resort dengan kualitas dan pelayanan terbaik. Selain itu tingkat kunjungan wisatawan asing maupun lokal terus mengalami peningkatan dari tahun ke tahun yang membuka peluang untuk dihadirkannya sebuah hunian Hotel Resort dengan fasilitas-fasilitas dan pelayan an yang terbaik, dan sebagai loncatan dalam merancang objek wisata arsitektural ini " Arsitektur Kontemporer" dianggap cocok menjadi tema perancangan dengan Pertimbangan identitas kebudaya yang saat ini mulai terlupakan, sehingga dengan rancangan Hotel Resort ini diharapkan dapat mengangkat nila-nilai budaya yang ada terlebih budaya Melayu Riau.Selain itu Arsitektur Kontemporer memiliki karakteristik sendiri yang dapat diterjemahkan dalam bahasa dan rancangan Arsitektur.
\end{abstract}

Kata kunci: Hotel Resort Wisata Danau Bandar Khayangan Lembah Sari Pekanbaru Arsitektur Kontemporer

\begin{abstract}
Hotel Resort is an architectural container in the form of residential lodging that is built to facilitate the local tourists or local tourists who come to Pekanbaru visit an area or a tourist attraction to enjoy the facilities or tourist attractions that exist.Keberadaan this container is quite a lot but still few who provide Residential Hotel Resort with the best quality and service.

In addition, the level of foreign and local tourist arrivals continues to increase from year to year which opens opportunities for the presence of a residential Resort Hotel with the best facilities and servants, and as a springboard in designing architectural attractions of this "Contemporary Architecture" is considered suitable to be the design theme with the consideration of the current cultural identity began to be forgotten, so with the design of this Resort Hotel is expected to lift the cultural values that exist, especially the Malay culture Riau.Selain Contemporary Architecture has its own characteristics that can be translated in the language and design of Architecture.
\end{abstract}

Keywords: Hotel Resort Tourism Lake Bandar Khayangan Sari Valley Pekanbaru Contemporary Architecture 


\section{PENDAHULUAN}

Berdasarkan kebijakan pemerintah Provinsi Riau, yang terbentuk kedalam sebuah visi Riau 2030. Yang salah satu isi nya yang berbunyi, Menjadikan Riau sebagai salah satu pusat kebudayaan melayu dan daerah kunjungan wisata di Asia Tenggara.

Danau Wisata Bandar Khayangan Lembah Sari terletak di Kelurahan Limbungan , Kecamatan Rumbai Kota Pekanbaru. Untuk samapai ke lokasi dapat menggunakan transportasi darat yang tempuh dengan perjalanan kurang lebih 10 kilometer dari pusat Kota Pekanbaru.wisatawan yang datang ke Kota Pekanbaru selain untuk menikmati wisata kuliner yang tersedia ,mereka juga suka berkunjung ke Danau Bandar Khayangan Lembah Sari dan Danau ini pernah jadi pertandingan Sky air saat PON XVIII tahun 2012.

Danau Bandar Khayangan Lembah Sari yang dahulu bernama Danau Buatan ini memililki luas genangan air sekitar 150 Ha.pada Kondisi permukaan air normal, Danau diasumsikan mampu menampung air sekitar 5,25 juta m3 dan dalam sejarah tidak pernah mengalami kekeringan meskipun musim kemarau tiba.saat musim penghujan dengan debit inflow yang cukup besar,permukaan air Danau akan tetap dapat dikontrol dengan baik dikarenakan dua sungai yang berfungsi sebagai spilwayyaitu sungai Limbungan dan sungai pengambang yang merupakan kedua anak sungai Siak.

Danau Wisata Bandar Khayangan ini sangat ramai dikunjungi oleh wisatawan lokal atau warga yang berekreasi pada saat hari libur, hari sabtu atau hari minggu.Pohon-pohon yang besar memberikan kenyamanan untuk sekedar bersantai bersama kelurga dan kerabat, ditambah dengan ada nya Hotel Resort dan restoran,fasilitas bermain anak-anak membuat kenyamanan saat berkunjung ke Danau Bandar Khayangan secara langsung dengan menggunakan sampan dayung dan speedboat yang telah disediakan.

Danau Bandar Khayangan Lembah Sari memiliki banyak potensi wisata, dan menjadi salah satu icon rekreasi. Dilihat dari Wilayah Pengembangan (WP II) Danau Bandar Khayangan Lembah Sari merupakan salah satu penujang WP II bagian pengembangan Kota Pekanbaru . Dengan dilestarikannya fisilitas dan pengolahan aktifitas pada Danau Bandar Khayangan Lembah Sari akan munculnya keinginan seorang untuk berkunjung dan menimati fasilitas yang di sediakan pada Danau Bandar Khayangan Lembah Sari tersebut.

Bapak Firdaus.,S.T,M.T, selaku wali kota Pekanbaru mengatakan beberapa Visi Danau Bandar Khayangan Lembah Sari (sumber : wawacara dengan warga Limbungan selaku pengunjung kawasan Danau Bandar Khayangan Lembah Sari / minggu, 19 maret 2017 ) adalah sebagai berikut:

Kota Pekanbaru sendiri merupakan salah satu Ibu Kota Provinsi Riau yang menjadikan Kota terbesar keempat di Sumatera. pemasalahan global yang salah satunya terdapat di Kota Pekanbaru ini.

a.Melestarikan kawasan lindung Danau Bandar Khayangan

b.Memfasilitasi area sepanjang pinggiran Danau Bandar Khayangan

c.Memfasilitasi wisata air Danau Bandar Khayangan

d.Menjadikan wajah objek wisata Pekanbaru

e.Pembebasan lahan warga yang terisolisir disepanjang kawasan

f.Menyediakan bebas lahan untuk pengebangan bisnis investor

Dapat di lakukan dengan menambah objek di Danau Wisata Bandar Khayangan Lembah Sari yang di lakukan Kota-Kota besar lainnya, namun alangkah lebih produktifnya jika objek Danau Wisata Bandar Khayangan Lembah Sari di fasilitasi dengan unit hunian jangka panjang, karena dapat berfungsi timbal balik dengan objek wisata. Lokasi yang mendukung unit hunian yaitu memiliki potensi view, seperti Danau Bandar Khayangan Lemabah Sari, fasilitas umum, dan cagar alam. dengan menginspirasikan konsep bangunan Kontemrporer yang menyatukan ruang dalam dengan ruang luar yang berada dikawasan Danau Bandar Khayangan supaya menjadi daya tarik hunian di Kota Pekanbaru.

Hotel Resort adalah suatu jenis akomondasi peristirahatan yang mempergunakan sebagian atau seluruh bangunan untuk menyediakan jasa penginapan,makanan dan miniuman, sarana fasilitas pelengkapan lainnya serta jasa bagi umum yang dapat mendukung dan memeperlancar kegiatan istirahat para tamu yang bertujuan untuk berwisata /berkreasi di daerah tersebuh, dan dikelola secara komersial

Hotel bertujuan untuk memberikan kenyamanan fisik dan psikologis penghuninya, 
serta ke privasian yang terjaga. Hal tersebut dapat dicapai dengan penyelesaian design secara arsitektural dan pemisahan kegiatan dan pada zona privat dan zona public,antara lain sebagai berikut :

Kegiatan Wisatawan

1.Kegiatan hunian seperti tidur ,mandi, makan, beristirahat, dan sebagainya di ruang tidur (privat).

2.kegiatan rekreasi dan relaksasi wisatawanb seperti berenang ,menikmati pantai, dan sebagainya, dilakukan di area public.

\section{METODE PENELITIAN}

Metode yang digunakan untuk mendapatkan datadata yang terkait dengan perancangandan"Perencanaan Hotel Resort Wisata Danau Bandar Khayangan Lembah Sari Kota Pekanbaru" ini adalah sebagai berikut:

\section{Studi Literatur}

Mengumpulkan dan menelaah data dari perpustakaan berupa karya ilmiah tugas Akhir Arsitektur , mahasiswa arsitektur serta buku-buku yang terkait dengan perencana dan perancangan mengenai Perencanaan ,Danau Wisata Bandar Khayangan Lembah Sari Pekanbaru

\section{Survey Lapangan}

Melakukan tinjauan langsung kelokasi site yang akan dirancang, untuk mendapatkan data-data mengenai : Ukuran Tapak, Jenis Tanah, Batasan pada Tapak, view, akses keluar dan masuk kendaraan, orientasi matahari, dll.

\section{Studi Wawancara}

Mendapatkan informasi dengan cara bertanya langsung kepada responden. Data semacam itu merupakan tulang punggung suatu penelitian survey.

\section{HASIL PENELITIAN}

Lokasi pada Tapak Perencanaan Hotel Resort Wisata Danau Bandar Khayangan Lembah Sari Pekanbaru
Lokasi tapak berada di Jalan Limbungan, Kecamatan Rumbai Persisir Kota Pekanbaru, di sekitar tapak terdapat bangunan pendukung seperti Thiater terbuka ,Toilet umum ,permainan wahana air ,Tempat duduk santai dan ditambah lagi dengan Musholla ,Luas tapak yang direncanakan sekitar $\pm 75.000 \mathrm{~m} 2$.

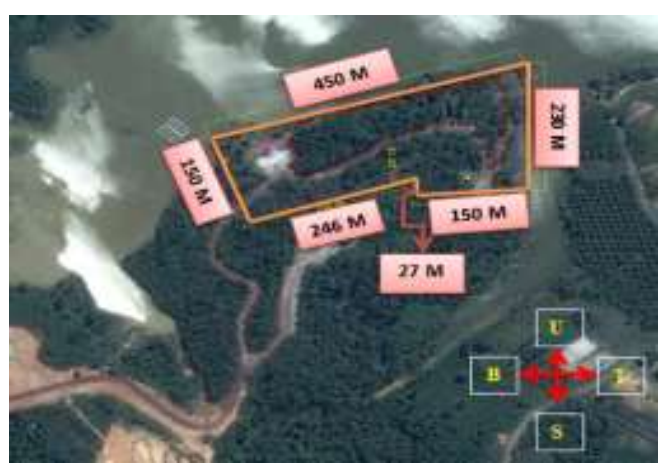

Gambar 1.Tapak Hotel Resort Wisata

\section{Kondisi Bangunan dan Lingkungan nya}

Dari survei lapangan ada beberapa bangunan dan lingkungan yang memerlukan fasilitas pendukung baik itu dari segi fasilitasnya maupun sarana dan prasarananya. Sehingga perlu dirancang Hotel Resort Wisata Danau Bandar Khayangan Lembah Sari Pekanbaru.

\section{Akses Jalan yang ada disekitar Tapak}

Untuk aksessibilitas/pencapaian dari luar sangat baik karena hanya ada satu akses masuk yaitu dari Jl.Limbungan dan satu akses keluar dari Jl.Limbungan.

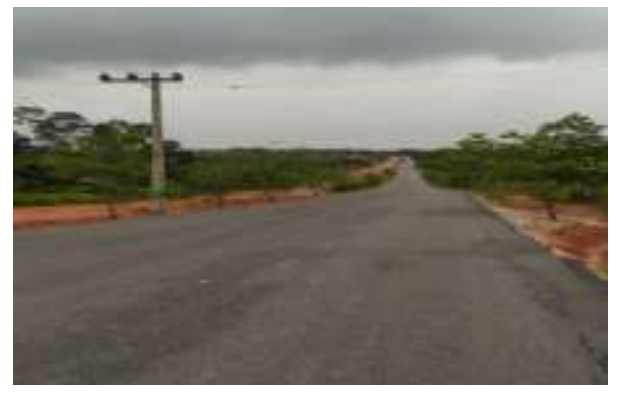

Gambar 2.Akses Jalan Masuk 


\section{Kondisi Dalam Tapak}

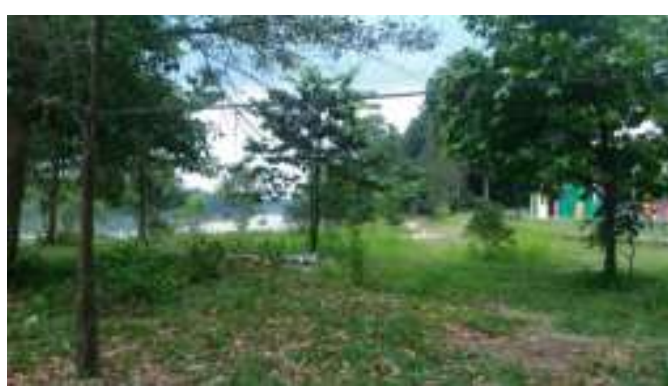

Gambar 3. Suasana didalam Tapak

\section{Bangunan disekitar Tapak}

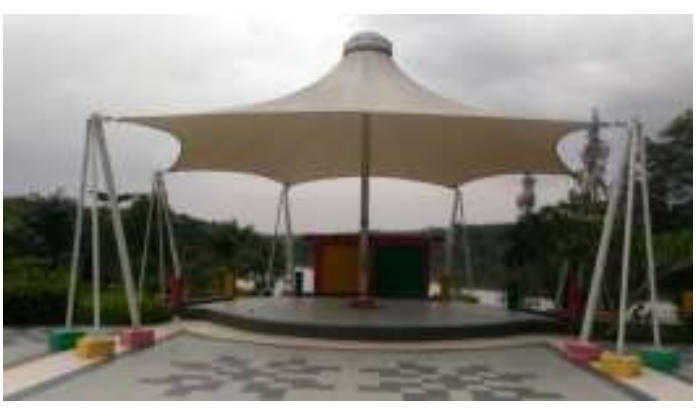

Gambar 4. Gedung Thiater terbuka

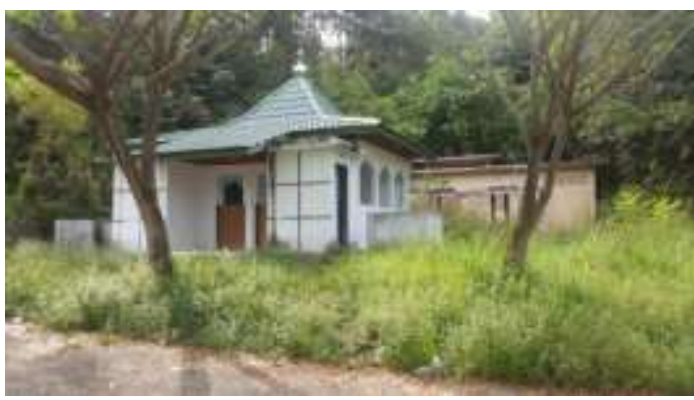

Gambar 5.Gedung Musholla

\section{Aspek Manusia}

Analisa aspek manusia merupakan hal yang penting bagi seorang perancangan dalam merangcang sebuah bangunan ,karena manusia merupakan pengguna dari pada bangunan tersebut.Diharapkan perancang dapat merancang sesuai dengan kriteria dan kebutuhan manusai sebagai pengguna bangunan.

Faktor manusia sangat penting di perhatikan saat mendesain sebuah bangunan, hal ini sangat berpengaruh terhadap ruang-ruang yang akan kita butuhkan. Pada faktor manusia ini terdapat 3 aspek yang sangat penting, yaitu :

1.Pelaku Kegiatan

2.Aktivitas Pelaku

3.Kebutuhan Ruan).

\section{Analisa Pelaku Kegiatan}

Pelaku kegiatan yang ada pada bangunan "Perencanaan Hotel Resort Wisata Danau Bandar Khayangan Lembah Sari Pekanbaru" adalah sebagai berikut

- $\quad$ Pengelola Hotel Resort

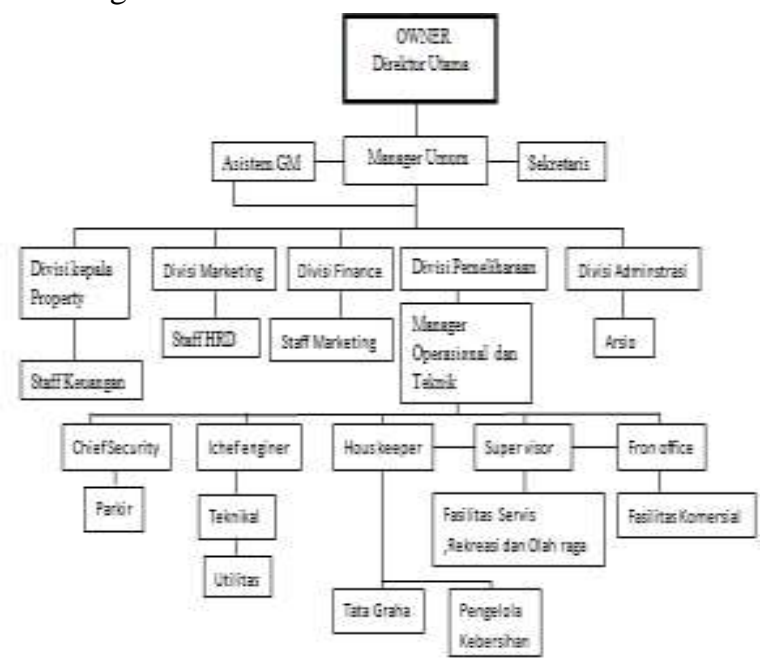

Skema 1. Alur kegiatan Hotel Resort

- Pengunjung Wisata

Skema 2. Alur kegiatan pengujung wisata

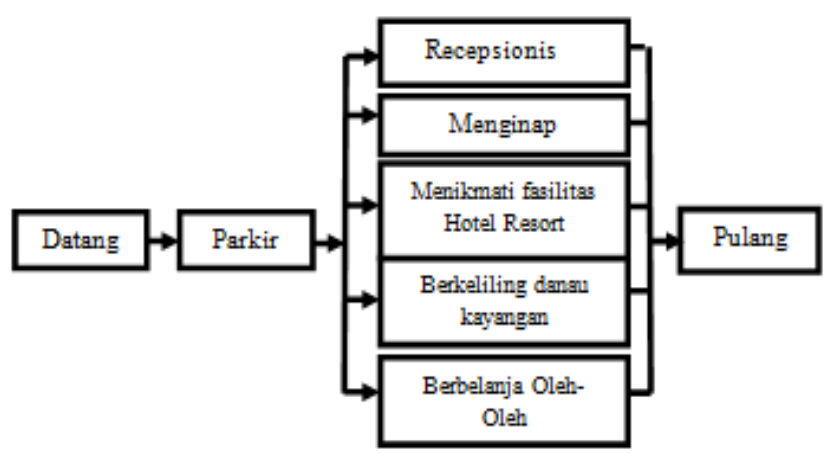

Skema organisasi ruang makro

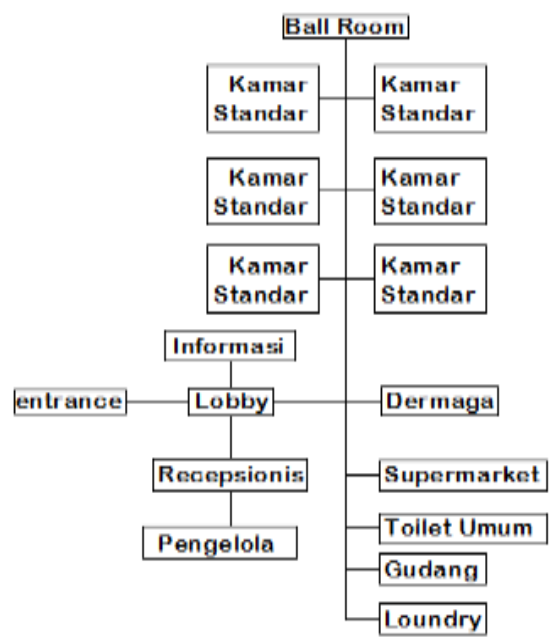

Skema 3.pola ruang makro 
Pola hubungan ruang mikro

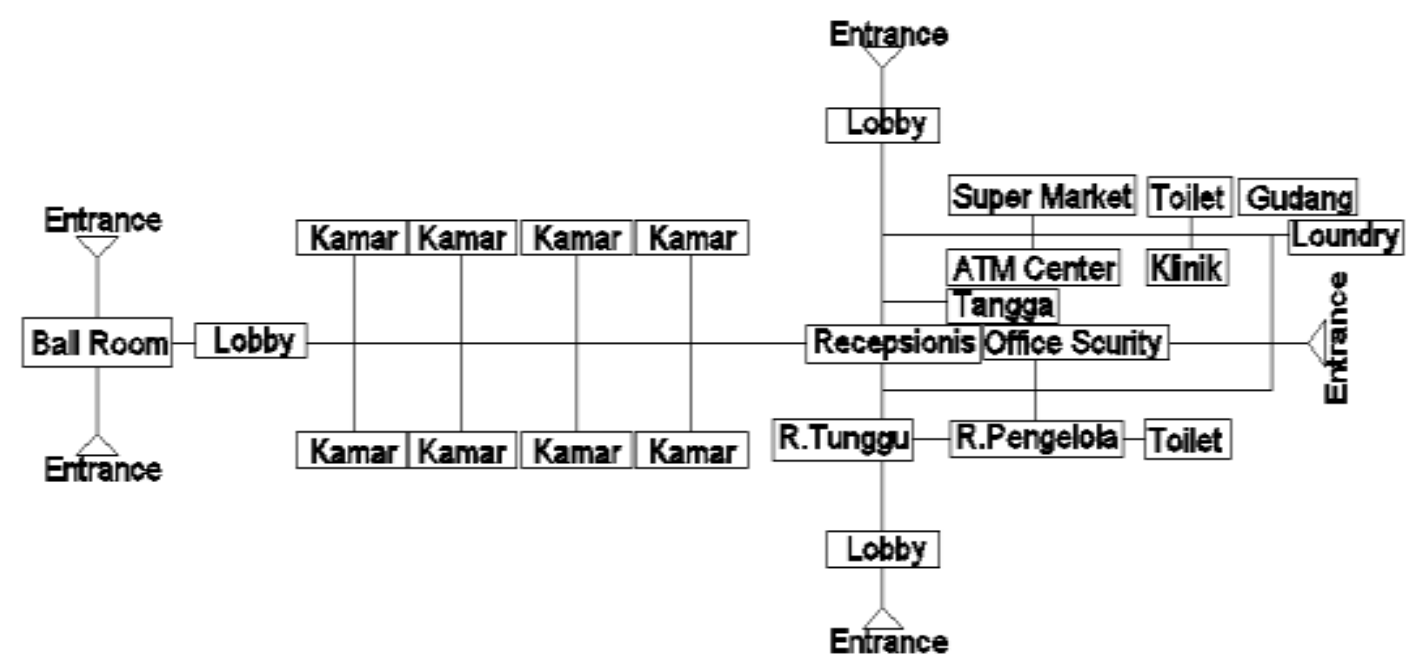

Skema 4.pola ruang mikro pengelola

Fasilitas servis

Fasilitas dalam hotel

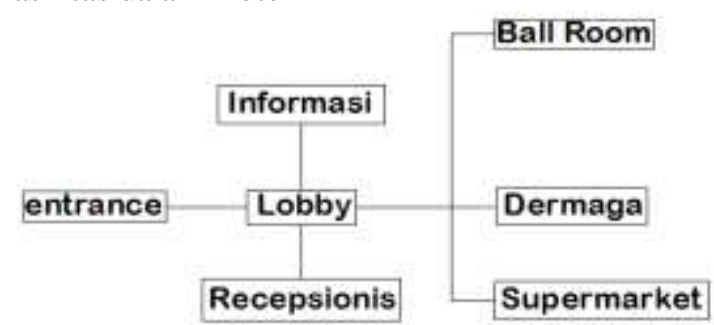

Skema 5.pola ruang mikro dalam Hotel

Pengunjung wisata

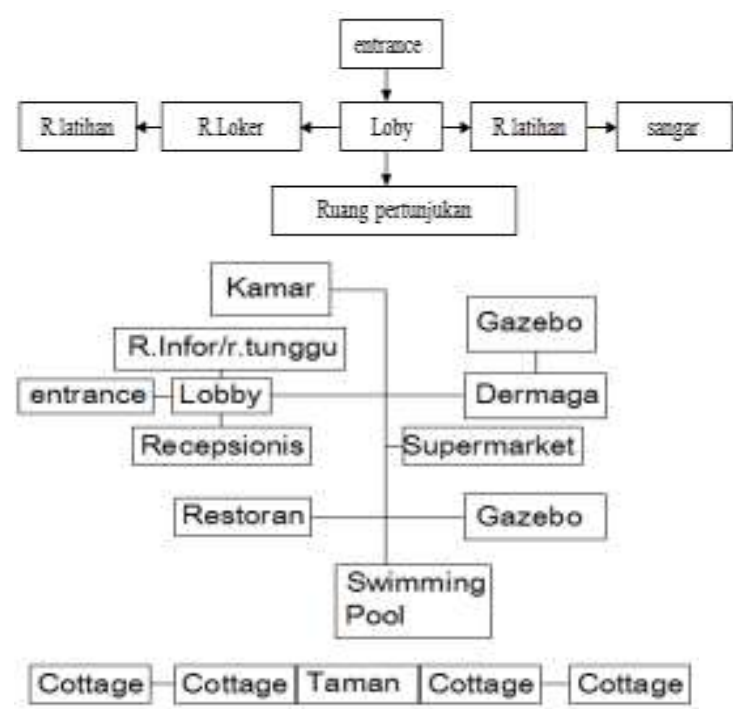

Skema 6.pola ruang mikro seni

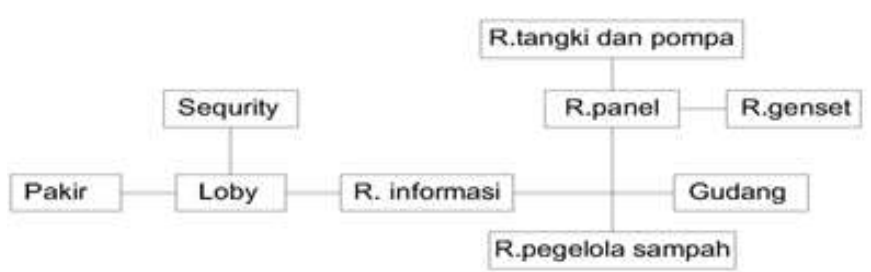

Skema 7.pola ruang mikro servis

Analisa Tapak

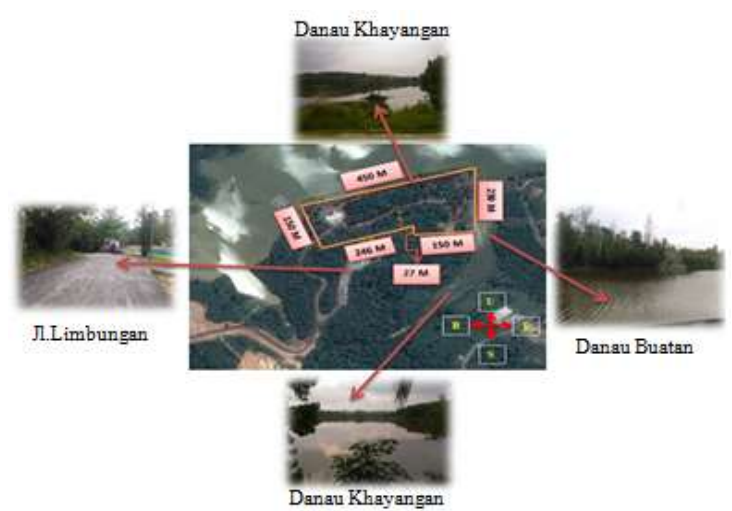

Lokasi Tapak Perencanaan Hotel Resort Wisata Danau Bandar Khayangan Lembah Sari Pekanbaru berada di Kecamatan Rumbai Persisir Kota Pekanbaru berada di jalan Limbungan. 


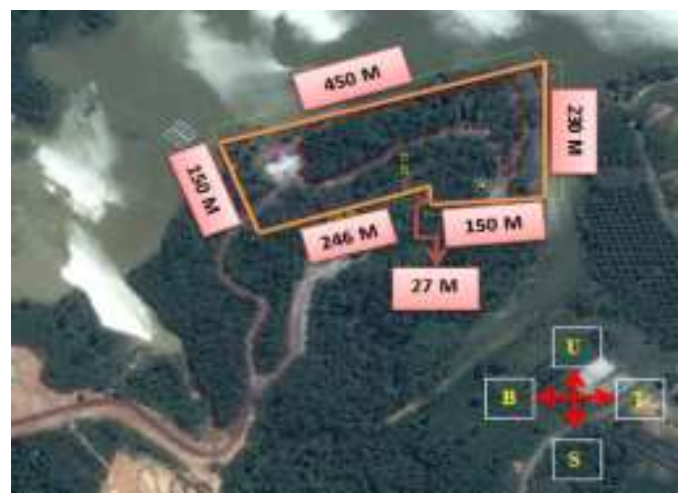

Gambar 6.Analisa Tapak

\section{Dimensi Tapak}

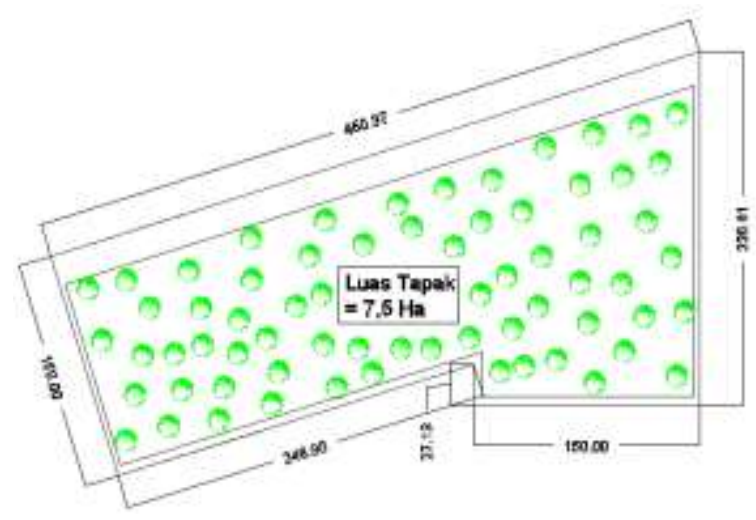

Gambar 7 : Dimensi Tapak

\section{Batas-Batas Dimensi Tapak}

\section{Tapak Exsiting}

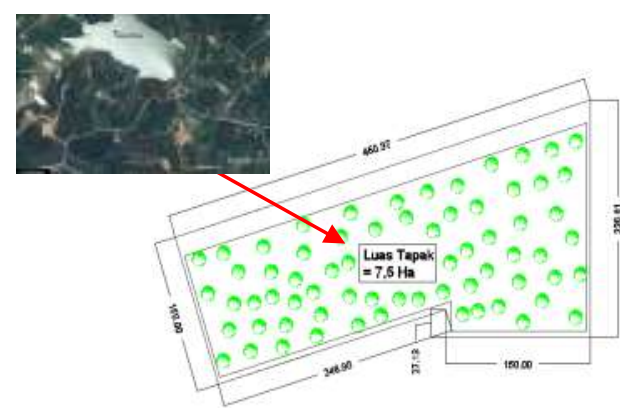

Gambar 8.Batas-Batas Tapak

\section{Analisa dari luar kedalam tapak}

Pada gambar berikut merupakan suasana atau pendangan yang diambil dari view luar kedalam tapak.

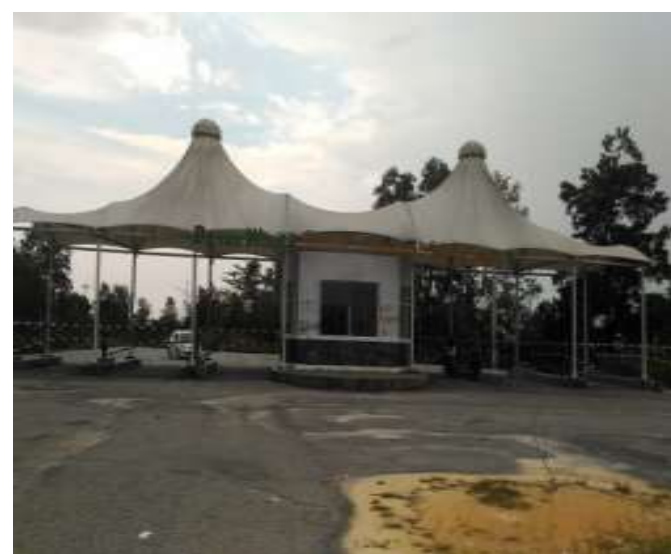

Gambar 9.Dari luar kedalam tapak

\section{Analisa Kondisi Tanah}

Perencanaan Hotel Resort Wisata Danau Bandar Khayangan Lembah Sari Pekanbaru dapat menjadi salah satu tempat Penginapan dan Rekreasi yang dapat dikunjungi dari luar kota pekanbaru. Oleh karena lokasi terpilih berada di jalan Limbungan .Kondisi tanah pada tapak yaitu:tanah keras.

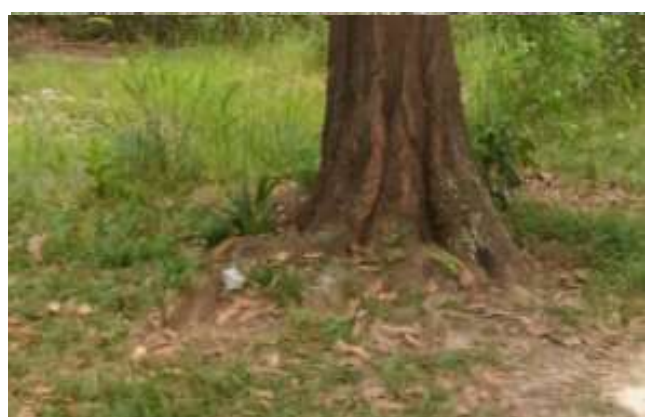

Gambar 10.Kondisi Tanah

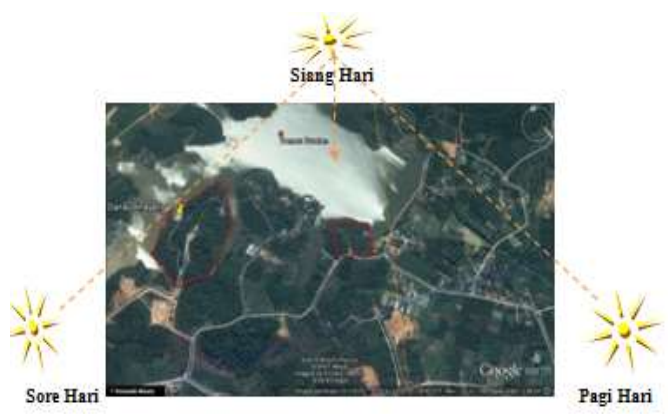

Gambar 11. Orientasi matahari

\section{Analisa Orientasi Matahari}

Dari analisa orientasi matahari terhadap tapak bahwasanya pengelompokan kegiatan-kegiatan yang nyaman terhadap kondisi tapak ialah berorientasi ke Timur 
karena mempertimbangkan bukaan terhadap sinar matahari pagi .

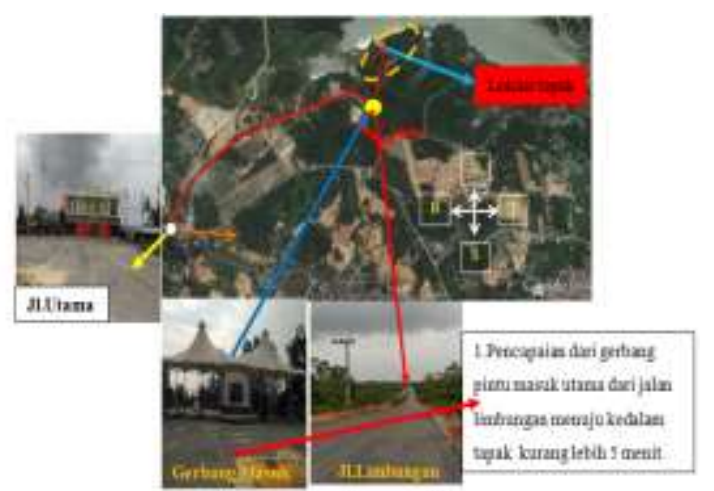

Gambar 12.Pencapaian

\section{Analisa Pencapaian dan Sirkulasi}

\section{Potensi}

Jalan menuju lokasi dilalui oleh kendaraan pribadi, angkot dan kendaraan roda 2 .

\section{Kendala}

1. Kemungkinan kemacetan yang diakibatkan oleh angkot dan jenis kendaraan disepanjang jalan mengakibatkan over kapasitas jalur kendaraan menuju tapak.

2. Intensitas kendaraan di perkirakan meningkat pada saat liburan dan hari-hari besar.

\section{Solusi}

3. Perluasan area sirkulasi kendaraan menuju tapak agar tidak terjadi kemacetan dijalan raya akibat antrian kendaraan keluar-masuk tapak.

\section{Analisis Kebisingan}

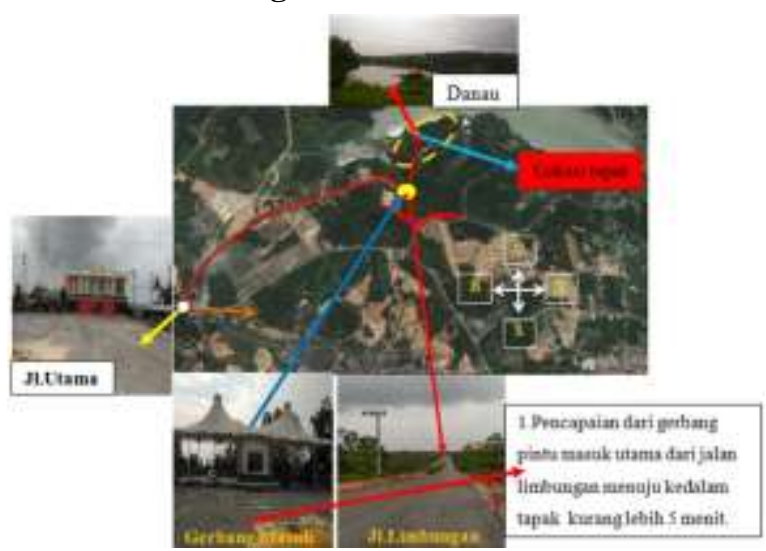

Gambar 13.Analisa view dan kebisingan

1. Kebisingan

Pada lokasi ini sumber kebisingan paling tinggi berada di Jl.Limbungan .Hal ini dikarenakan karena jalan tersebut merupan jalan Utama yang banyak dilalui oleh kendaraan.

Untuk mengurangi kebisingan akibat kendaraan bermotor, sebagai solusi desain dari halini maka di lakukan:

1. mempertahankan pohon dan tanaman peredu sebagai buffer hidup yang dapat mengurangi tingkat kebisingan sekaligus polusi udara.

2. Zoning ruang yang sensitif terhadap kebisingan di jahukan dari sumber kebisingan.

\section{Penzoning Tapak}

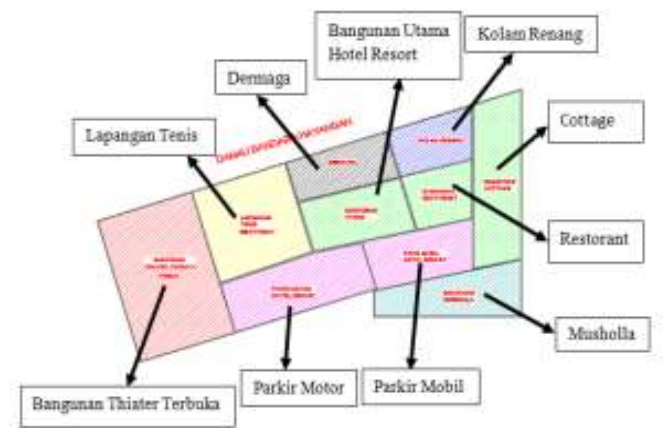

Gambar 14.penzoningan

\section{Analisa Pemikiran Zoning Bangunan}

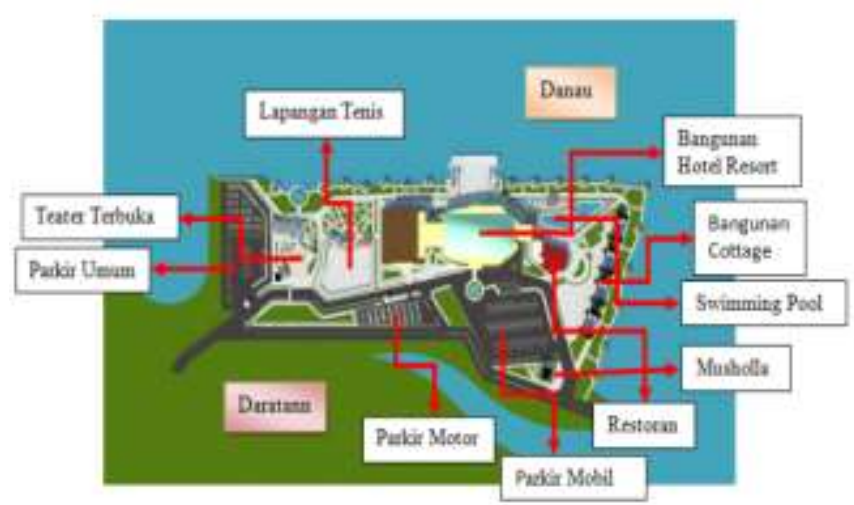

Gambar 15.Analisa pemikiran

Konsep zoning pada tapak berdasarkan pada Fungsi Masing-masing.Alur pembagian zoningnya berdasarkan fungsi agar pengorganisir zoning utama menghadapi danau bandar khayangan menjadi lebih jelas.

\section{Analisa Regulasi}

adapun regulasi yang telah ditetapkan oleh pemerintah mengenai aturan antara lain : 
KDB( Koefisien Dasar Bangunan )KDB menurut perda kota Pekanbaru no.14 tahun 2000 menurutut perda Kota Pekanbaru berdasarkan RUTR (1991-2015 ), setiap bangunan apabila tidak ditentukan, KDB maksimum 80\% (delapan puluh perseratus) untuk bangunan fungsi usaha, $80 \%$ (delapan puluh perseratus) untuk bangunan fungsi hunian, $60 \%$ (enam puluh perseratus)

\section{Analisa topik dan tema}

Topik : Arsitektur Kontemporer

Tema : Penerapan Rancangan pada Bangunan dengan mengikuti tampilan dan bentuk pada prinsifprinsif Arsitektur Kontemporer

Analisis Hotel Resort Wisata di Kecamatan Rumbai Persisir Kota Pekanbaru berdasarkan tema yaitu pendekatan perancangan terhadap bentuk dan Prinsif-prinsif Arsitektur Kontemporer yang ada.

Adapun Prinsif-prinsif Arsitektur Kontemporer itu sendi sebagai berikut :

A. Konsep bangunan terbagi 3 yaitu :

1. Bentuk variatif dan inovatif serta tetap mencerminkan fungsi sebagai pusat komersial

2. Penyesuaian terhadap Prinsif-prinsif Arsitektur Kontemporer

3. Penggunaan beberapa teknologi modern

\section{Analisa Struktur}

Struktur bangunan adalah bagian dari sebuah sistem bangunan untuk memikul beban secara aman dan efektif, Beban yang bekerja pada bangunan serta menyalurkannya ke tanah melalui pondasi.

Analisis struktur pada bangunan Hotel Resort Wisata Danau Bandar Khayangan Lembah Sari Pekabaru adalah sebagai berikut:

A. Pondasi tiang pancang
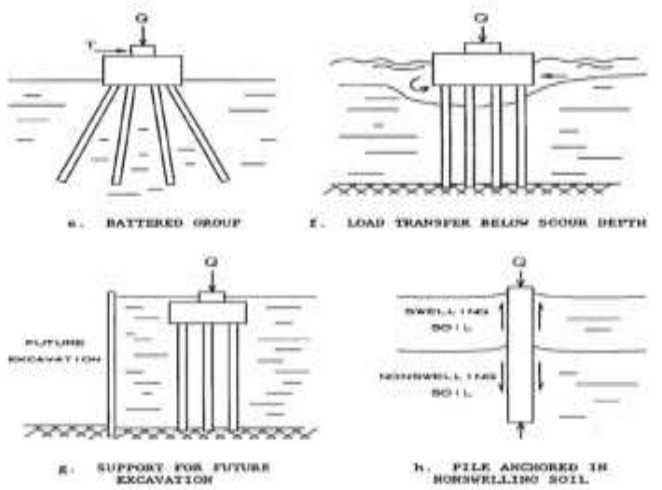

Gambar 16.pondasi tiang pancang

\section{Konsep Dasar Perencanaan Hotel Resort}

$$
\text { Konsep dasar "perencanaan Hotel }
$$

Resort Wisata Danau Bandar Khayangan Lembah Sari Pekanbaru" ini berlandaskan pada topik Arsitektur Kontemporer, yaitu arsitektur kontemporer adalah keyakinan bahwa terdapat suatu hubungan logis antara fungsi dan bentuk sebuah bangunan (buku Komposisi Arsitektur Ed.1.)

Istilah kontemporer juga sama artinya dengan modern atau sesuatu yang up to date, tapi dalam disain kerap dibedakan. Istilah ini digunakan untuk menandai sebuah disain yang lebih maju, variatif, fleksibel dan inovatif, baik secara bentuk maupun tampilan, jenis material, pengolahan material, maupun teknologi yang dipakai.

Secara garis besar, konsep rancangan yang ingin di terapkan ialah :

a.Bentuk variatif dan inovatif serta tetap mencerminkan fungsi sebagai pusat komersial

b.Penyesuaian terhadap Prinsif-prinsif Arsitektur Kontemporer

c.Penggunaan beberapa teknologi modern.

\section{Konsep zoning Tapak}

Konsep Penzoningan Pada Tapak Berdasarkan analisa ada 10 zoning perancang, penempatan zona-zona pada tapak di pertimbangkan berdasarkan 


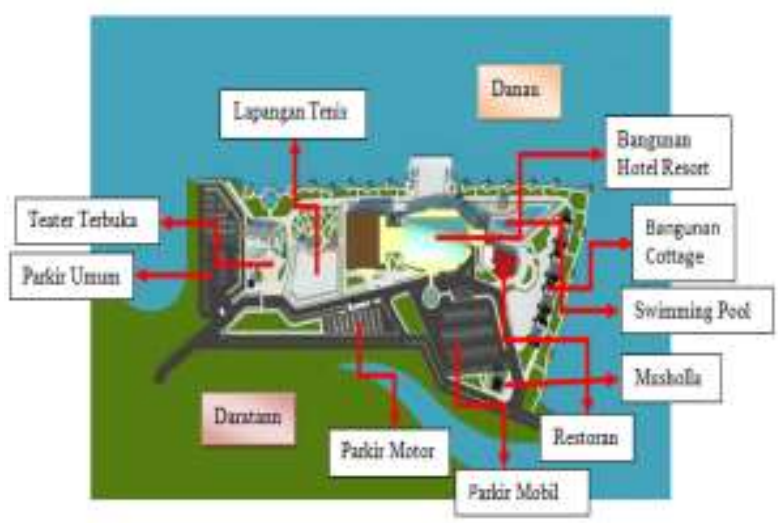

Gambar 17. Konsep zoning Tapak

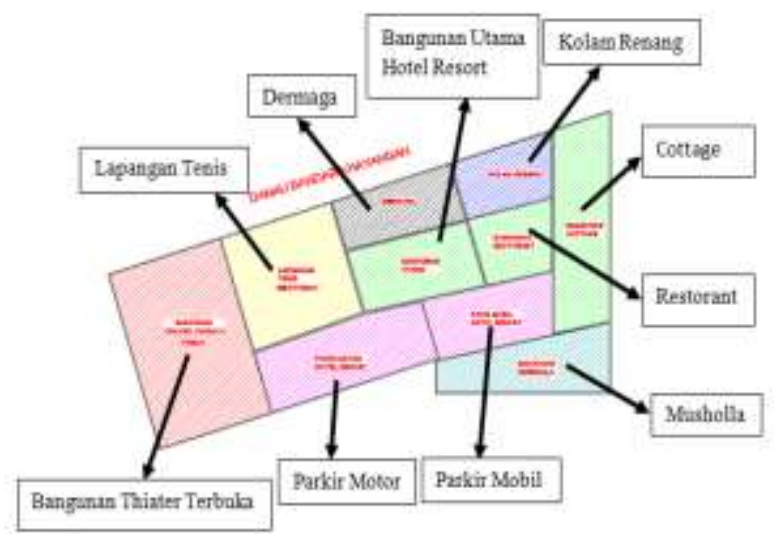

Gambar18.Konsep zoning kegiatan

Konsep zoning pada tapak berdasarkan pada Fungsi Masing-masing.Alur pembagian zoningnya berdasarkan fungsi agar pengorganisir zoning utama menjadi lebih jelas mengarakan kedepan danau bandar khayangan.

\section{Konsep Sirkulasi}

Dalam konsep sirkulasi pada Hotel Resort Wisata Danau Bandar Khayangan Lembah Sari Pekanbaru ini di bagi menjadi 2 bagian yaitu :

1. Ruang Luar Aktif adalah ruang luar yang menampung kegiatan manusia meliputi parkir dan sirkulasi kendaraan. adapun bentuk sirkulasi parkir yang digunakan ialah parkir sudut $45^{\circ} / 90^{\circ}$.
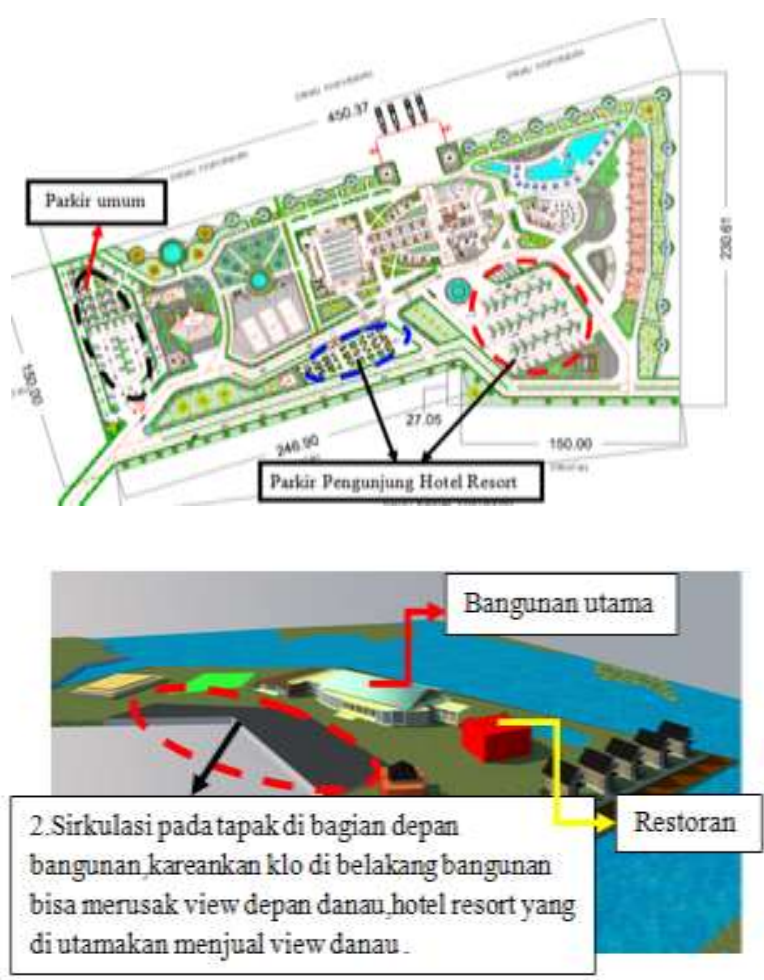

Gambar 19. Konsep Sirkulasi parkir

Konsep sirkulasi parkir untuk kendaraan roda empat dan roda dua di pisah agar mempermudah aktifitas kendaraan untuk masuk menuju kedalam tapak maupun ke luar tapak dan tidak menganggu aktifitas di luar tapak.

\section{Konsep Sirkulasi dalam tapak}

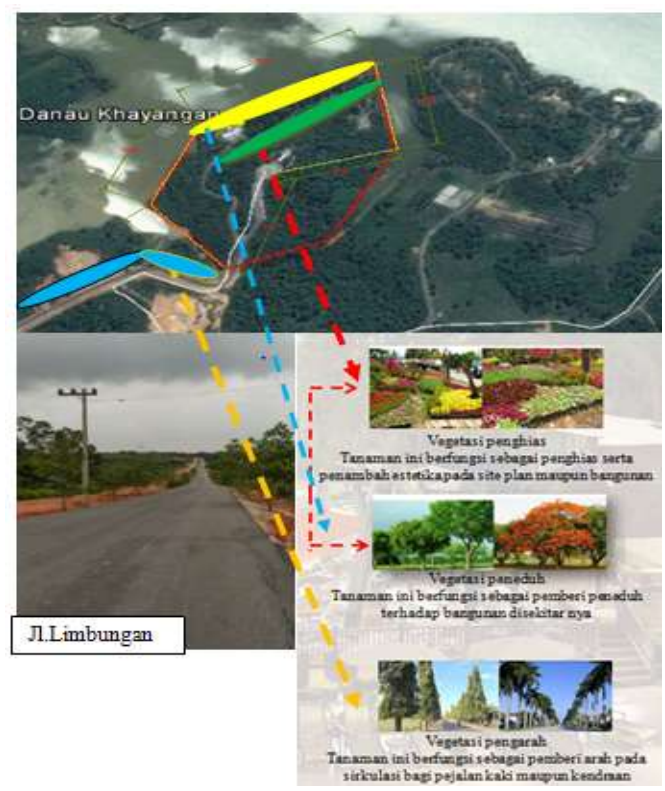

Gambar20. Konsep Sirkulasi ruang dalam 
Konsep sirkulasi yang digunakan pada Hotel Resort Wisata ini mengunakan sirkulasi terpisah antara mobil dan motor ini akan diterapkan dengan upaya dan tujuan yang di tuju. Pengunaan Sirkulasi ini lebih mudah di capai kendaraan roda empat dan roda dua.

\section{Konsep kebisingan}

Konsep kebisingan pada tapak yaitu untuk menangani kebisingan mengunakan penerapan sistem vegetasi yang difungsikan sebagai peneduh dan menetralisir kebisingan dan sebagai penyerap udara.

Dari jalan Limbungan tingkat kebisingan yang paling tinggi berada pada Nomor 1 dan Sedangkan tingkat kebisingan yang sedang yaitu berada pada Nomor 2 dikarenakan jalan menuju kedalam tapak cuma memilik 1 akses jalur masuk dan jalur keluar dari jalan limbungan.

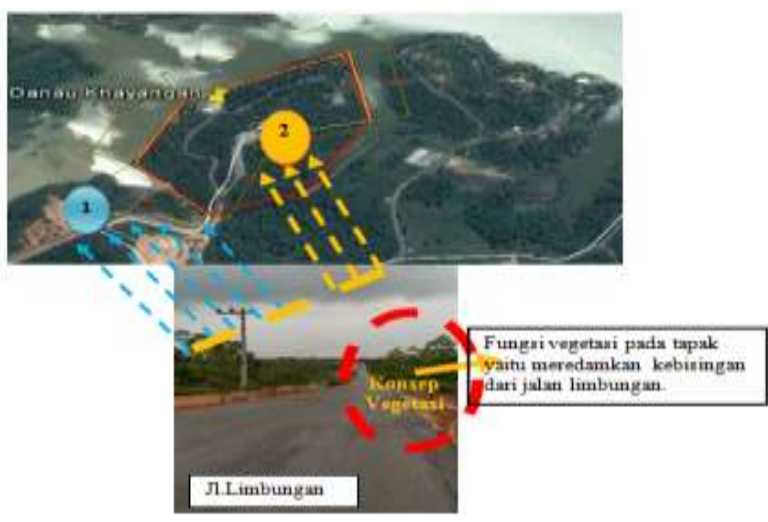

Gambar 21. Konsep kebisingan

\section{Konsep Vegetasi}

Gambar 22. Konsep Vegetasi

Jenis Vegetasi ada 3 sebagian berikut ini:

1.Vegetasi penghias

2. Vegetasi peneduh

3. Vegetasi pengarah

\section{Konsep Masa Bangunan}

Konsep masa bangunan pada gedung Hotel Resort Wisata Danau Bandar Khayangan Lembah Sari Pekanbaru ini lebih mendekatkan kepada proses atau tahapan - tahapan dalam program melalui pendekatan tampil dan bentuk mengikuti tapak pada bangunan.

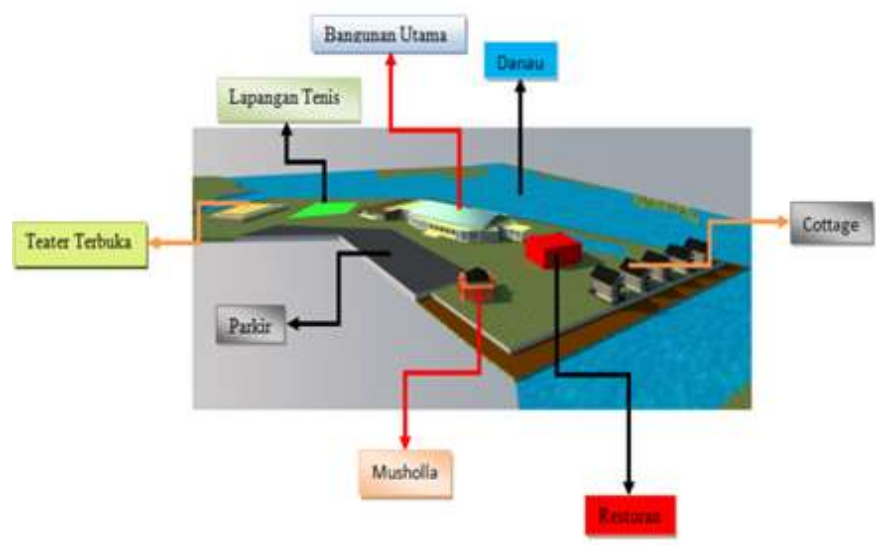

Gambar 23. Konsep Masa Bangunan

\section{Konsep Gubahan Masa Bangunan}

Konsep gubahan masa bangunan yang diterapkan adalah bentuk yang disesuaikan dengan karakter tapak dengan pertimbangan pemanfaatan kontur, orientasi matahari, view danau, vegetasi disesuaikan dengan konsep dasar pembangunan .

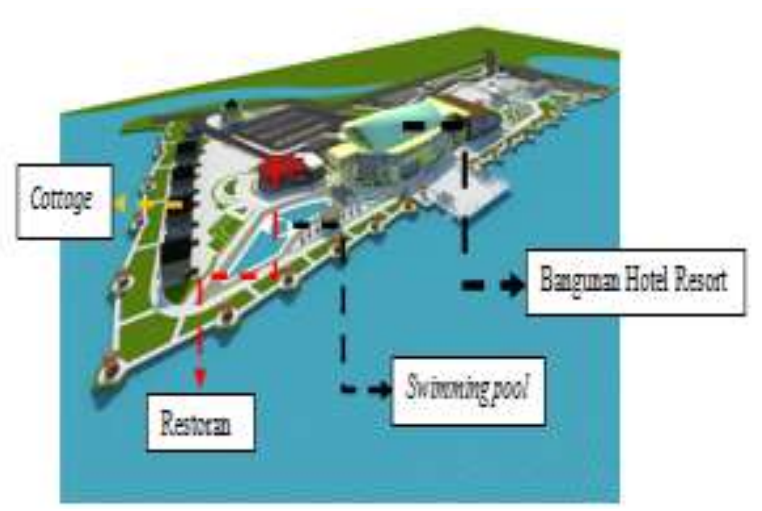

Gambar 24. Konsep Gubahan Masa Bangunan

Hasil Perancangan Hotel Resort Wisata

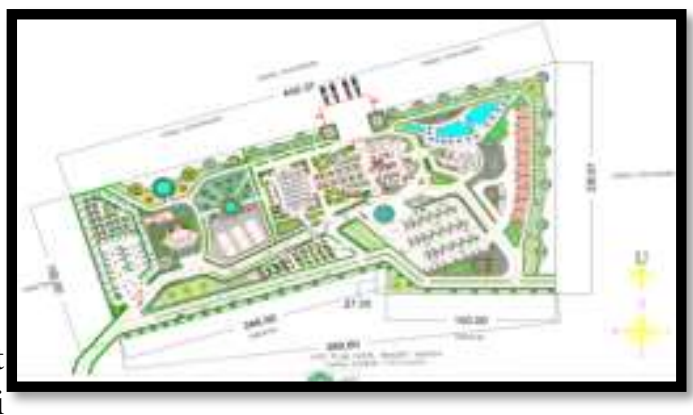

Gambar 25. Site Plan Hotel Resort Wisata 


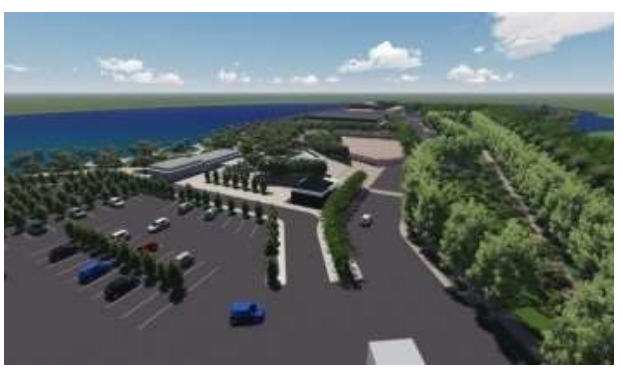

Gambar 26. Perspektif 1

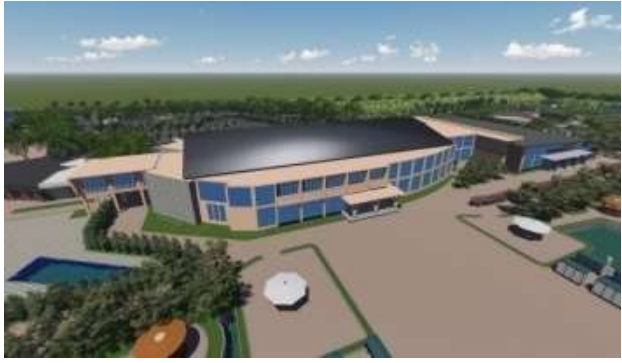

Gambar 27. Perspektif 2

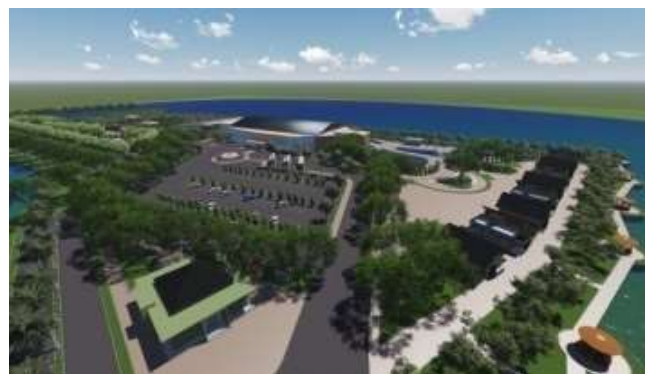

Gambar 28. Perspektif 3

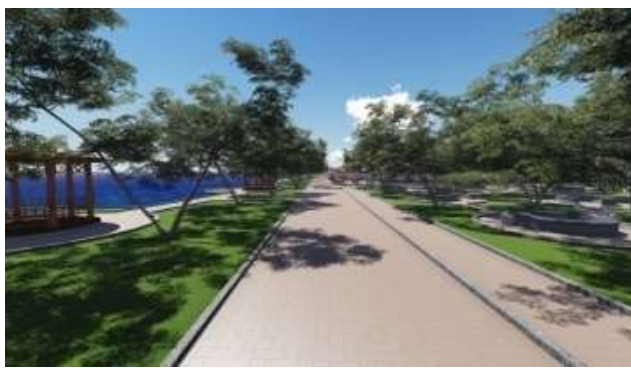

Gambar 29. Perspektif 4

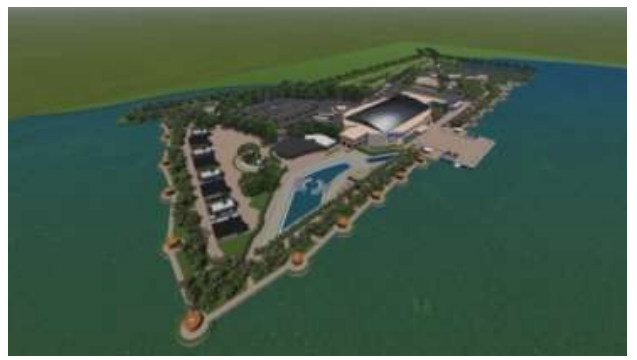

Gambar 30. Perspektif 6

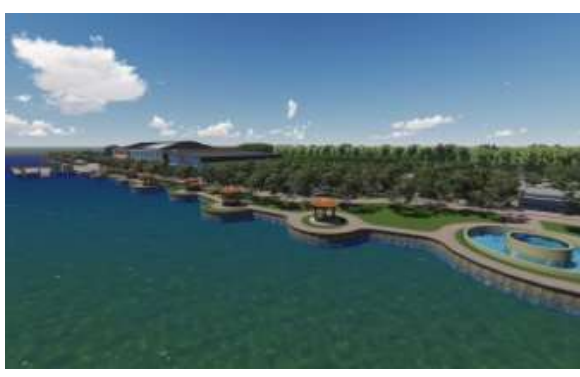

Gambar 31. Perspektif 7

\section{KESIMPULAN DAN SARAN}

Perencanaan Hotel Resort Wisata Danau Bandar Khayangan Lembah Sari Pekanbaru" sebagai pusat wisata Kota Pekanbaru .

Lokasi Tapak perancangan yang sangat strategis, yakni tepat berada di Jl.Limbungan Rumbai Pesisir potensi untuk menjadikan "Hotel Resort Wisata Danau Bandar Khayangan Lembah Sari Pekanbaru" karena lokasi sangat bagus dan dekat dengan Masyarakat Pekanbaru, dan tempat wisata danau bandar khayangan potesinya bagus Sehingga ramai yang dikunjungi datang kedanau bandar khayangan ini.

Besar harapan dalam "perencanaan Hotel Resort Wisata Danau Bandar Khayangan Lembah Sari Pekanbaru" ini adalah untuk dapat mewadahi kegiatan yang berkaitan dengan wisatawan sebagai tempat penginapan dan rekreasi hiburan untuk masyarakat kota pekanbaru sendiri.

\section{UCAPAN}

Ucapan terima kasih ku persembahkan untuk Kedua orang tua, kakak-kakak ku, dan adek ku dan sahabat-sahabat ku tercinta.Semoga semua bantuan yang telah diberikan kepada saya dapat bermanfaat buat saya pribadi semoga kebaikan dibalas dengan kebaikan dan pahala oleh Allah SWT.Amin .

\section{DAFTAR PUSTAKA}

[1] Frick Ch. Koesmartadi, Heins,Ilmu Bahan Bangunan, Eksploitasi, Pembuatan, Penggunaan Dan Pembuangan.Penerbit Kanisius. 
[2] Ching,D.K,Francis dan Cassandra Adams, 1985, Ilustrasi Kontrusksi Bangunan,Penerbit Erlangga.

[3] Ching,D.K,Francis.1985,Arsitektur:BentukRuang dan Tatanan, Jakarta : Erlangga

[4] Pengertian Arsitektur Kontemporer :Buku Komposisi Arsitektur Ed 1 Neufert, Ernest, 1996,Data Arsitek JILID 1Edisi 33.Penerbit Erlangga, Jakarta

[5] Neufert, Ernest, 2002, Data Arsitek JILID 2 Edisi 33.Penerbit Erlangga,Jakarta

[6] Peraturan Menteri Pariwisata dan Ekonomi Kreatif Republik Indonesia Nomor: PM.106/PW.006/MPEK/2011 Tentang Sistem Manajemen Hotel.

[7] Peraturan Menteri Pariwisata dan Ekonomi Kreatif Republik Indonesia Nomor PM.53/HM.001/MPEK/2013 Tentang Standar Usaha Hotel.

[8] Peraturan Daerah No.04 Tahun 2004 Tentang Rencana Induk Pengembangan Pariwisata Provisi Riau.

[9] Undang-Undang Republik Indonesia Nomor 10 Tahun 2019 Tentang Kepariwisataan . Kementerian Pariwisata Republik Indonesia 2016 